\title{
Reframing the role of knowledge parks and science cities in knowledge-based urban development
}

\author{
Paul Benneworth \\ Center for Higher Education Policy Studies, University of Twente, The Netherlands; \\ e-mail: p.benneworth@utwente.nl \\ Tiago Ratinho \\ Department of Marketing and Entrepreneurship, Merrick School of Business, \\ University of Baltimore, MD 21201, USA; e-mail: tratinho@ubalt.edu \\ Received 25 March 2012; in revised form 23 December 2013; published online 24 June 2014
}

\begin{abstract}
Knowledge-based urban developments (KBUDs) are an increasingly common element of urban planning and strategy making: policy makers and developers set out to stimulate economic prosperity by promoting the integration and concentration of research, technology, and human capital. But KBUD is, by its advocates' own admission, a fuzzy concept, assuming that local physical development will drive urban upgrading within wider innovative production networks. We seek to address one element of this confusion by exploring how physical developments actively create innovative connections between local actors, drawing on the microscale science park and incubator literature. Using the case of one knowledge precinct, Kennispark in the east of the Netherlands, we investigate how active and passive elements of KBUDs drive integration of knowledge infrastructure in the urban fabric, as a prerequisite to building cross-city connections. On the basis of both qualitative and quantitative data, we conclude that there is a dynamic interrelation of proximity and connectivity within the precinct that contributes to building within-city knowledge communities that may in turn lead to improved cross-city connectivity and hence urban upgrading.
\end{abstract}

Keywords: knowledge-based development, knowledge-based urban development, urban scale, urban innovation, science parks, technopoles

\section{Introduction}

Many cities seek to compete on the basis of knowledge production and innovation. Many related policy concepts have emerged over recent decades, placing science centrally in the city, including technopoles, science cities, knowledge quarters, and innovation districts (Castells and Hall, 1994; van Winden et al, 2007). Emphasis shifted from particular campuses' characteristics to their contribution to their host cities' development. Perry and May (2010) and Yigitcanlar and Velibeyoglu (2008) conceptualised this as knowledge-based urban development (KBUD). But Perry (2008) identified a confusion within KBUD concepts around simplifying built form, innovation activities, and growth outcomes in urban areas (cf Forsyth, 2014). We concur with Perry that KBUD remains a thinly spatialised concept, focusing on globally connected innovative actors and not on how they interact and affect places' local innovation dynamics (cf Benneworth and Dassen, 2011; Sarimin and Yigitcanlar, 2012). The confusion in KBUD concepts relates to a 'missing middle' between understanding local activities and how that drives urban upgrading (Smith, 2014). KBUD concepts elide from global actors' presence to stimulate urban upgrading, similar to the 'necessary but not sufficient' fallacy that in the 1990s saw policy makers chase 'high-tech' foreign investments as a panacea for upgrading old industrial areas (Lovering, 1999; Phelps and Tewdwr Jones, 1998). 
We therefore argue that more emphasis needs to be placed on relating physical precincts operations to wider urban upgrading.

To do this, we draw on longstanding debates around proximity and connectivity (Amin, 1999; Lagendijk, 2011) from earlier generations of technopole analysis (cf Castells and Hall, 1994; Longhi and Quéré, 1993). In this paper we focus on one particular kind of KBUD concept, knowledge community precincts (KCPs) (Yigitcanlar, 2010), physical developments bringing together diverse groups of globally connected actors to stimulate urban creativity and innovation. We reconceptualise KCPs as producing upgrading effects through a three-step process: creating a precinct, stimulating within-city connections, and improving cross-city connections (the upgrading effect) (Coe et al, 2004; Nijkamp, 2003; Smith, 2003). We argue that a return to understanding proximity and local connectivity suggests a need to distinguish two kinds of KCP. First is passively anchoring globally connected knowledge actors in the same location (cf Kim et al, 2014). Second is actively promoting connectivity between these actors to construct critical mass, spillovers, and competitiveness, building creative, innovative communities (Blažek and Žížalová, 2010; Etzkowitz, 2012). We focus on these two classes of within-city effect-passive and active - to pose the following questions.

- How do these effects function within KCPs, driving territorial upgrading within urban hierarchies?

- How can we conceptualise these elements in a more integrated KBUD theory?

We address those two questions via a KCP case study, Kennispark (Knowledge Park) in the eastern Netherlands. We argue that whilst KBUD and KCP theories pay much attention to passive elements, a failure to understand active community-building processes, and the dynamics of the wider 'knowledge connectivities' (Lindkvist, 2005) within which they are embedded, hinders developing a strong link to KCPs building cross-city connectivity. We argue that future KBUD research should focus more on exploring these knowledge community-building dynamics, whilst policy making should promote constructing and anchoring those local knowledge communities to drive urban upgrading.

\section{Literature review}

\section{A first model of KBUD driving global connectivity}

KCP theory implicitly argues that specific localities attract globally connected actors, thereby upgrading the city's position within wider urban networks (May and Perry, 2011). These wider international networks represent a set of the 'cross-city' relationships within which particular KCPs are embedded (Benneworth et al, 2014; Livi et al, 2014), and KCPs seek to influence how global connections 'place' cities in transnational innovation networks. KCP theory implies a model whereby precincts upgrade places within particular transnational innovation networks by creating rich local ('within-city') environments for knowledge exchange that are attractive to external actors. We contend that part of the confusion of KCP arises from a simple elision in how these precincts make places more attractive to outside partners, the following step in the KCP process. We argue that these rich local environments can be understood in terms of two separate literatures, territorial knowledge overspill and territorial knowledge management.

Firstly, a set of territorial literatures conceptualises local innovation's embeddedness within multinational sectoral innovation systems (SISs) (Cooke, 2005; Mattes, 2006; Storper, 1995). A single site agglomerating globally connected proximate knowledge actors creates opportunities for intensive knowledge exchange and innovation: KCPs' 'precinct' elements are a first step in creating later opportunities for building connectivity at the interurban and even international scale within these SISs. Secondly, policy analysis literatures identified the contingency of proximity in producing real connectivity and interaction between globally 
connected proximate knowledge actors within KCPs, the 'knowledge community' elements (Asheim et al, 2011; McCann and Ortega-Argilés, 2013). Associative collaboration norms and governance arrangements maximise actors' within-city connectivity, optimising and ultimately upgrading cross-city connectivity within their SISs (Cooke and Morgan, 1998; Liebovitz, 2003; Wolfe, 2010).

These two KCP effects are clearly interrelated, both active and passive-creating passive opportunities for globally connected actors to interact, but also actively managing and encouraging those actors' interactions. Where successful, these together drive urban upgrading within a wider hierarchy. Thus, ideal-type (KCP) processes include two within-city elements: a diverse, well-connected knowledge ecology (passive); and activities integrating those disparate elements (active). These two elements create new material activities that in turn may have cross-city effects, potentially driving urban upgrading (see figure 1).

On that basis, our research questions are therefore:

- How do (passive proximity and active connectivity) effects function within KCPs, driving territorial upgrading within urban hierarchies?

- How can we conceptualise these elements in a more integrated KBUD theory?

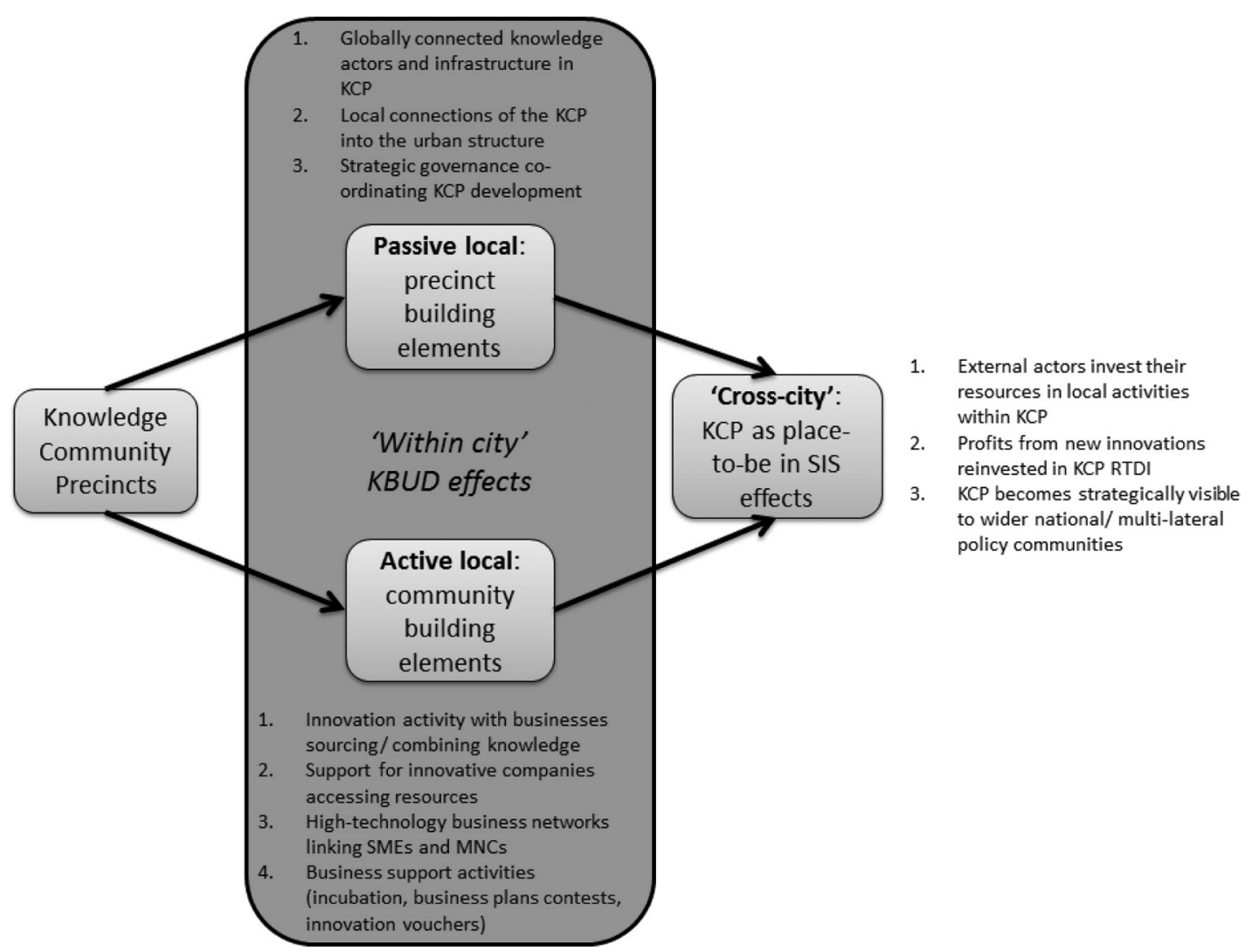

Notes: $\mathrm{KPC}=$ knowledge community precinct; $\mathrm{SME}=$ small and medium-sized enterprise; $\mathrm{MNC}=$ multinational corporation; SIS = sectoral innovation system; RTDI = research, technical development, and innovation

Figure 1. Knowledge-based urban development (KBUD) upgrading the urban situation in wider hierarchies (source: authors' own design). 


\section{Passive and active elements in KCPs \\ The passive element in KCPs-proximity}

KBUD concepts understand knowledge being created within wider networks, making actors' connectivity critical for place-specific competitiveness (Amin and Roberts, 2008; Coe et al, 2004). Likewise, territorial innovation models (TIMs) conceptualise knowledgebased development as innovative businesses cooperating locally, interacting face-to-face to facilitate transferring tacit knowledge, and drawing on extraterritorial knowledge to generate export sales (Asheim et al, 2007; Benneworth et al, 2014; Crevoisier, 2014). Innovative actors create shared assets that can be understood as 'pools' of knowledge capital (Huggins and Johnston, 2009; Lawton Smith, 2007; Moulaert and Sekia, 2003; Storper, 1995).

"The proximity among companies achieved in such 'knowledge precincts' is essential to stimulate learning and create compatible knowledge spillover effects (Hu et al, 2005)" (Yigitcanlar, 2010, page 1771).

But there is a tension within TIMs between whether proximity is necessary or sufficient for stimulating regional innovation. Certainly, three elements can be distinguished by which KCPs can contribute to urban upgrading without necessarily improving local connectivity. Firstly, they may attract globally connected knowledge actors to locate within a city, and that these actors may employ staff who are mobile but territorially located with the opportunity to move between firms, taking their specific knowledge with them (cf Storper, 1995). Secondly, KCPs can facilitate 'local buzz' by integrating and connecting these knowledge actors into a wider urban environment by fitting with the existing infrastructure (Bathelt et al, 2004). Thirdly, KCPs may 'fit' with public policy actors' interests, ensuring that appropriate public sector resources are made available to support private sector knowledge investments (Benneworth et al, 2011). We therefore define our three KCP passive elements as:

(1) globally connected knowledge actors and infrastructure in $\mathrm{KCP}$;

(2) local embeddedness of the KCP into the urban infrastructure;

(3) strategic governance coordinating KCP development.

KCPs are specific locations within a city, where actors form communities, sharing knowledge, innovating, and creating these positive returns to scale (Yigitcanlar and Velibeyoglu, 2008). Proximity has been problematised as a contingent and emergent phenomenon regarding the transfer of knowledge, and its relationships with nonlocal connections (cf Amin, 1999; Coe et al, 2004; Håkanson, 2005; Lagendijk, 2011; Lagendijk and Oïnas, 2005). Ignoring this creates simplistic cause-effect narratives or quintessentially 'happy family stories' (Lagendijk and Oïnas, 2005) where creating an attractive physical space helps local actors win more external $\mathrm{R} \& \mathrm{D}$ investments, thereby driving urban upgrading. Clearly, these local knowledge pools' dynamics and their territorial consequences need be understood in terms of their wider connectivity (Benner, 2003; Roberts, 2014).

We argue that this contingence or emergence regarding creating strong local interactions that can improve external connectivity is missing or at best implicit within KCPs (Amin and Roberts, 2008; Etzkowitz, 2012; Gertner et al, 2011; Håkanson, 2005; Lawton Smith, 2007). KCPs may host knowledge communities which become localised spaces of situated knowledge (cf Loasby, 1998) that are also 'places to be' (following Gertler, 2003) for wider 'knowledge collectivities' (Lindkvist, 2005) to access that situated knowledge. Extant KCP conceptualisations often overlook the ways these communities are not just born with global connections but can be actively and strategically constructed (Lagendijk, 2013). This lacuna frames KCPs as passive science-based physical regeneration schemes, ignoring their active role in constructing regional advantage (Asheim et al, 2007; 2011; cf Lagendijk, 2007), and we argue that this is the source of the confusion Perry identifies. 
The active elements in KCPs-connectivity

To understand these active community-building elements, we use a close reading of the science parks (SPs) literature (cf Amirahmadi and Saff, 1993; Massey et al, 1992). These spaces have identifiable management teams and activities, typically focusing on both knowledge agglomeration and resource sharing (Phan et al, 2005), concentrating university or research centres, knowledge-based companies, young and established firms, and ancillary service companies. SPs have become embedded in universities' missions (Link and Scott, 2003) and policy makers' imaginaries (Benneworth and Hospers, 2007a) as a bridge between universities and business - stimulating entrepreneurial science (Popp Berman, 2011). Modern SPs act as codevelopers of new companies, addressing all phases of the innovation process, from R\&D to commercialisation (Hansson et al, 2005), actively managing and facilitating knowledge exchange, both between tenants but also with the wider environment (Bigliardi et al, 2006; Ratinho and Henriques, 2010). This notion has been gaining ground parallel to the business incubation movement (EC, 2002; Knopp, 2007) and has increasingly integrated tools for business support into science park portfolios (Bøllingtoft, 2012; Bruneel et al, 2012; Patton et al, 2009).

The SP literature has devoted attention to some connectivity elements including innovative output (Löfsten and Lindelöf, 2002) or incubation activities (McAdam and McAdam, 2008). Miller (2014) argues that SPs as a form of innovation intermediary play three rolesnamely, creating strategic linkages between knowledge producers and exploiters, offering services supporting innovation, and filling gaps in innovation processes where knowledge producers and exploiters are too far apart. We add a fourth element: filling gaps within innovation networks by supporting entrepreneurship and new firm formation (Glückler, 2007). The four elements of within-city connectivity we use are therefore:

(1) innovation activity with businesses sourcing and combining knowledge;

(2) support for innovative companies accessing resources;

(3) high-technology business networks linking small and medium-sized enterprises (SMEs) and multinational corporations (MNCs);

(4) business support activities (incubation, business plans contests, and innovation vouchers).

\section{Methodology}

We investigate one KCP, 'Kennispark', in Enschede, eastern Netherlands, where policy makers have attempted since the late 1980s to create a technopole around the regional university. Since 2001, regional partners have increasingly emphasised building a KCP spanning the university and its adjacent SP. The development has also seen relatively little improvement in the cross-city connectivity elements-whilst Eindhoven's High-Technology Campus has clearly improved its position in global networks, a demonstrable upgrading in terms of Enschede's position within key SISs is more debateable (Benneworth and Ratinho, 2014). Kennispark represents an useful example to explore KBUD in those nonexceptional circumstances.

\section{Operationalisation of constructs}

Established in 1999, the Kennispark is now home to more than 400 business and 6000 jobs. Data were collected both quantitatively and qualitatively to better understand Kennispark's creation and evolution; qualitative data consist of a combination of previous research by one of the authors, grey literature on Kennispark's creation, and other public domain information as cited. Quantitative data were collected between March and May 2011 via an inventory of all Kennispark companies and a survey of their business service use and their sources of innovation (for businesses reporting innovation in the preceding year). 
We operationalise proximity effects through three variables. Firstly, we look at the composition of the knowledge infrastructure within the KBUD. Universities, research institutions, as well as private businesses can be part of this infrastructure. These organisations' presence is a defining characteristic of SPs throughout the world (see, for instance, Phan et al, 2005) and a well-discussed topic in urban studies (Moulaert and Sekia, 2003). Ideally, these institutions are well connected with each other but equally globally integrated.

Secondly, we will search for connections of the KBUD to the urban structure, as suggested by Perry and May (2010). This ranges from the presence of complementary infrastructure for employees of the business and science park (BSP) to accessibility to public transportation. We will discuss the location of the Kennispark relative to the city and its developments.

Finally, we look at the strategic coordination of the BSP activities. Both industry and researchers see active management as a defining condition to SPs and incubation activities (Amirahmadi and Saff, 1993). Further, knowledge districts have also reportedly introduced local coordination of activities to facilitate interaction between all institutions (Hu et al, 2005; cited in Yigitcanlar, 2010).

We operationalise connectivity into four indicators. Firstly, we will study the distribution of high-tech, knowledge-based service, and spin-off companies. These categories are chosen given their popularity among policy makers and urban developers as a means to promote job creation and economic prosperity (Norrman and Bager-Sjogren, 2010; Shane, 2009).

We also have a closer look at incubation activities, mostly searching for physical and virtual incubators. Business incubators have become ubiquitous in today's economy, supporting new businesses by providing infrastructure and an array of business support activities, and facilitating professional networks (EC, 2002; see also NBIA website at http://www.nbia.org). Thirdly, we consider the ways in which high-technology business networks link SMEs and MNCs within the knowledge precinct. Finally, we explore connectivity built through the creation of new high-technology businesses through Kennispark's active entrepreneurship programmes.

\section{Qualitative: the Kennispark case study}

We utilise the case-study method to contextualise the foundation, development, and current situation of one representative urban science project, the Kennispark. We approach the problem from a critical realist perspective: we construct a narrative of reality which we use to test our research problems; we acknowledge that there are limitations to the reality, which can be revealed through case-study work, but a triangulation of evidence allows something meaningful to be said about the nature of 'reality'. This is not strictly speaking a case study in the sense of Yin (2008), typically selected as fitting the needs of testing a theoretical question. Our approach is that an extant example appears to be an interesting illustration of a theoretical phenomenon, and deeper examination of the case provides insight into our heuristic's architecture. The heuristic concerns the relationship between the KCP's active and passive elements: the case study provides a single illustration of how these elements relate in a single contex - how they interact - and may be suggestive of more systemic relationships in a more coherent and explicit KCP theory between the different KBUD elements. The case study is part of an ongoing work programme concerning the University of Twente's (UT) regional impact, and we therefore draw on other work within this programme, published elsewhere as referenced in this case study (Benneworth and Hospers, 2007a; 2007b; Benneworth et al, 2011) but also within OECD (2007) and Garlick et al (2006).

\section{Quantitative: company inventory and surveys}

We used the official chamber of commerce $(\mathrm{CoC})$ database to inventory the Kennispark population of companies. Providing data to this register is a legal requirement of all Dutch located companies, providing a time-lagged and restricted dataset of basic company information. 
The information is on the basis of legal entities which do not necessarily correspond to real activities. This database includes numbers of employees, legal status, and sector of economic activity. The register reported a total of 433 firms located in the postcodes corresponding to the Kennispark area. After inventorying all legal organisations based in the Kennispark, we sent a survey to all companies, manually excluding the university, research institutes, and foundations. Of the remaining companies, we succeeded in finding valid email contacts for 234. We then sent a web-based survey to those and received responses from 67. Of those, 52 were valid questionnaires and are used in the subsequent analysis, giving an overall response rate of approximately $22 \%{ }^{(1)}$

The survey included seven main question areas exploring the nature of the business, its key resource dependencies, and reasons for location at the Kennispark. We asked questions relating to both the regularity with which support services were needed by the innovating firms, and their frequency of usage. The list of services used was derived from literature and cross-checked with Kennispark management to ensure that those services are in fact available within the park. The choice of Kennisvraag (Dutch for 'knowledge demand') is a specific service offered on the Kennispark by which innovating firms with a knowledge demand can contact a specialist advisor who will help direct them to possible providers of answers drawn from the local university, polytechnic, consultant, business, or student sectors.

Further, we asked about the sources of innovation to those companies reporting that they have introduced innovative products or services in the year before our survey (38 out of $52 ; 72 \%$ ). The questions were derived from the latest Community Innovation Survey and sought to identify the extent to which there were patterns of 'creative location behaviour' suggestive of the emergence of a new knowledge district. We asked tenant companies whether they launched innovation into the market in the last calendar year (2010). To those answering yes, we assessed the degree of importance of internal, market, institutional, and other sources using a four-point Likert scale.

\section{Introduction to the Kennispark case study}

The word Kennispark first occurs in a policy document in the municipality in 1999, although the UT's economic involvement in its region has a longer pedigree. Twente's fortunes were long determined by its textiles industry, which entered decline following World War II, when it faced competition from low-wage countries. The university was created to solve these problems in 1961, with the explicit mission of revitalising the textiles industry.

However, the university was not able to reverse textiles' steady decline, and from the mid-1970s the university reoriented itself towards working at creating new industries (van Boom and Mommaas, 2009). In 1982 the university negotiated with the regional development agency, the municipality, and the Control Data Corporation (CDC), to create a business technology centre (BTC) to the south of the campus. ${ }^{(2)}$ In 1989 the BTC's success led the municipality to create a BSP surrounding the BTC, in partnership with the university.

${ }^{(1)}$ We have calculated our sample's independence in relation to the whole population of the KBUD tenants, and nonparametric testing shows no significance on age and sector or activity. We did find statistically significant differences in size between the population of the Kennispark and our subsample of survey respondents, the latter being on average smaller. Nevertheless, we do not consider this difference as a source of bias to our results, for three reasons: (1) our argument about connectivity of companies does not mention at any point the influence of company size; (2) a few (four) medium and large corporations residing in the KPC caused the skewed distribution of company size: these are legal and accounting firms that we would never expect to be connected with each other with the aim of innovating; (3) companies in our sample may be smaller due to their early stages of development, and are more likely to engage with others seeking innovation sources or services.

${ }^{(2)}$ As with later strategic developments, this was significantly inspired by external best practices, here by CDC's BTC in Minneapolis St Paul. 


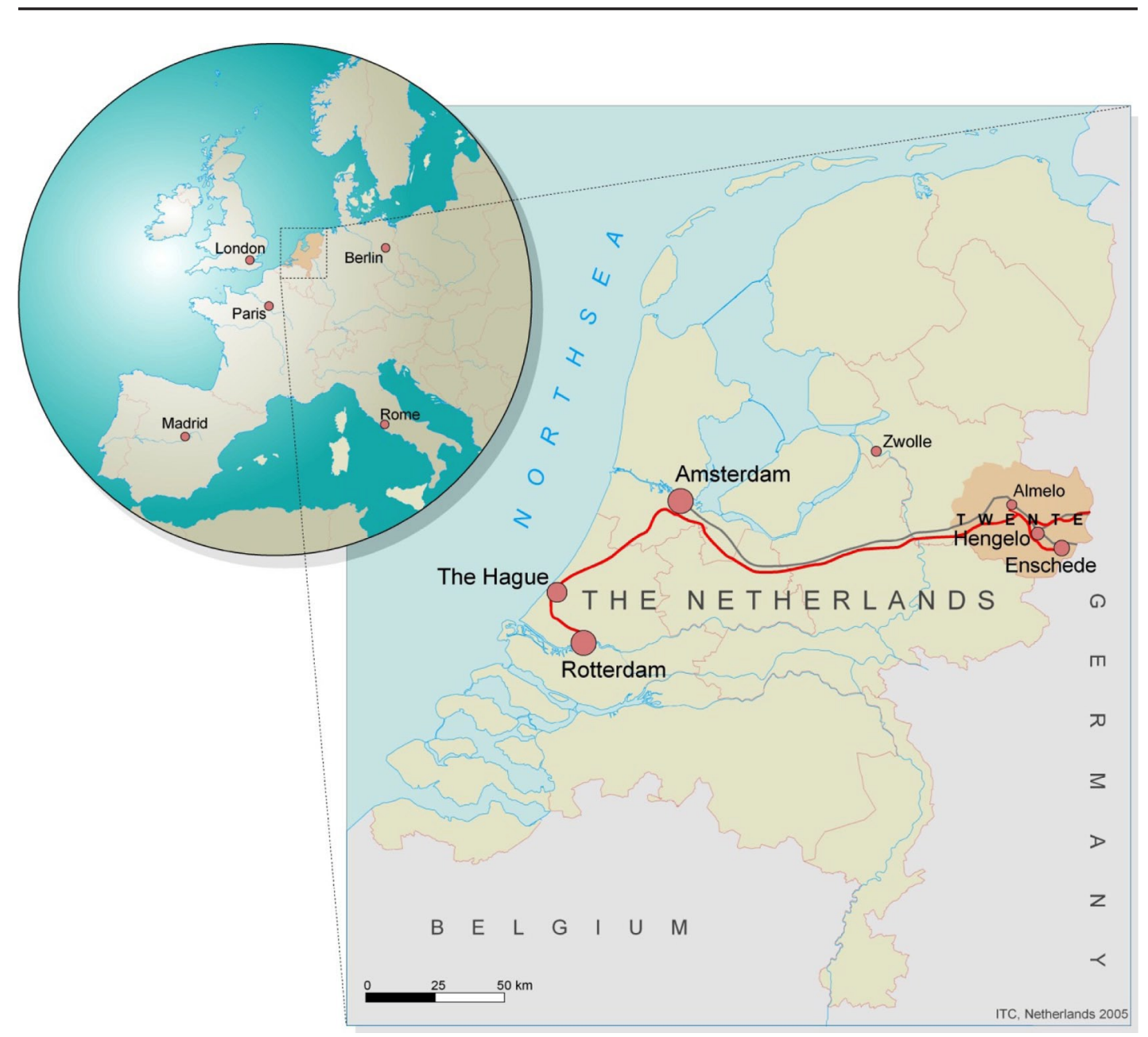

Figure 2. [In colour online.] The location of the region of Twente in Europe.

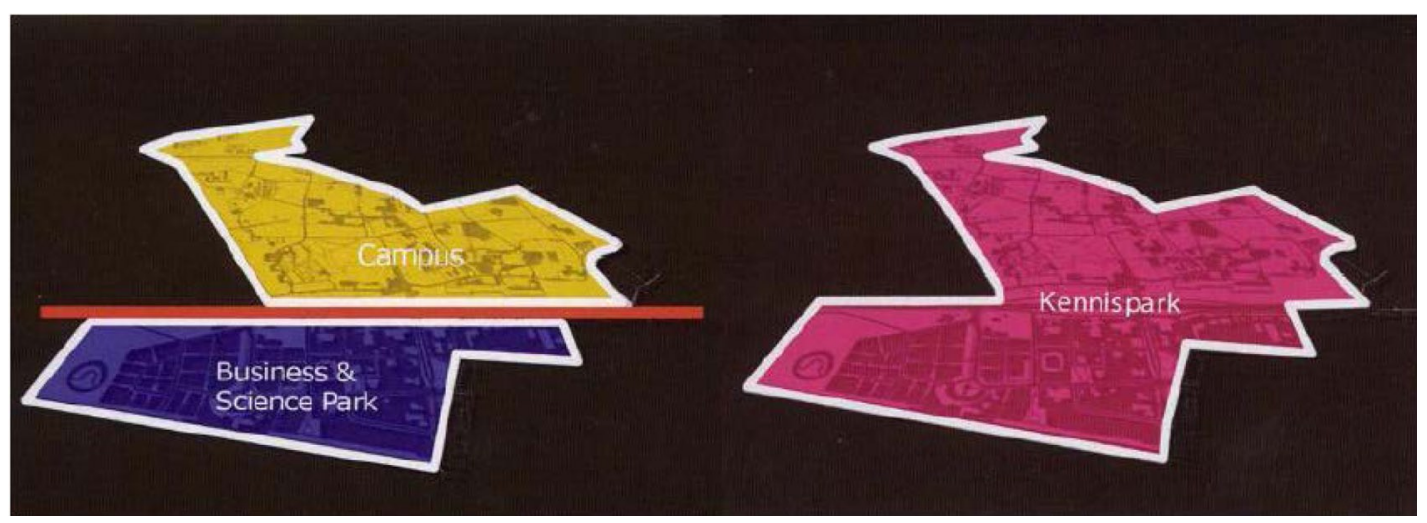

Figure 3. [In colour online.] The Kennispark concept at the time of the economic crisis, around 2004. 
The BSP was based on a formal covenant between the university and Enschede municipality, which expired after a decade. In 1999 the Kennispark idea emerged when partners met to discuss renewing that covenant, and was given additional impetus in the next five years by three regional crises: the 2001 high-technology crash; the university's estate reaching the end of its life (2002); and the closure of a Dutch Air Force base (2004) employing around 1500 people. In developing a strategic regional growth plan, these partners specified the Kennispark plan more precisely, reorienting the university and BSP into a single 20 ha high-technology space, a flagship for external investment. The stable Kennispark notion settled around three elements: creating a meeting place for innovative, entrepreneurial, and creative people; strengthening Twente's regional innovation capacity; and strengthening the synergy between knowledge and practice (Stuurgroep Kennispark, 2008).

\section{The urban-scale KBUD benefits of Kennispark}

To explore Kennispark's within-city KPC benefits, we distinguish between passive (proximity) and active (connectivity) effects (see table 1). Table 1 summarises these findings, the data sources from which they are derived, and their relationships back to our conceptual framework.

\section{Proximity elements}

Globally connected knowledge actors and infrastructure in KCP

Kennispark brought together many globally connected actors in a compact site: we here distinguish six kinds of actor. The first is the UT, comprising many research groups active in international research programmes (eg, European Framework Programmes) as well as publishing and attending conferences. Second are local companies with technologies specifically related to the university knowledge, including recent spin-off firms, firms started by students and graduates, and more mature successful spin-outs. Third are a number of multinational technology companies located on or engaged with Kennispark specifically to cooperate with local firms. Fourth are a number of technology investors, both local and external, investing in technology opportunities around the Kennispark site, channelling external resources (eg, national health insurance premiums) into research activities located within Kennispark. Fifth are property investment companies which have invested in the Kennispark site as a straightforward business investment, to generate private returns in return for investing in science park assets. ${ }^{(3)}$ Finally are a range of service companies that support these companies, including Kennispark, the BTC, but also private high-technology service companies.

One clear proximity effect comes through the creation of a specialised labour market. CoC data highlight how Kennispark contains four subzones: UT, the BTC, an incubator unit [the socalled VentureLab Twente (VLT)], and the business locations on the former BSP. These four zones host 433 organisations in postcodes which correspond to Kennispark; 165 are established in the UT campus while the BSP (excluding the BTC and VLT) houses 211, the BTC houses 46 companies, and VLT houses 11. However, a side effect of UT's quarter century of innovation activity has been a proliferation of zero-employee 'foundations' to encourage cooperation, to meet the needs of European funding projects, and to insulate the university from risky marginal or peripheral activities. Of the 433 organisations, 105 are foundations; there are 91 sole-traders, 200 limited companies, 23 partnerships, 3 cooperatives, and 2 joint stock companies, which act as holding companies for groups of larger trading activities. One third of all companies do not have employees, and one quarter of those with at least one employee have just one employee; $85 \%$ of Kennispark's firms have fewer than

(3) Previous buildings in the BSP were commercially financed and provided their investors with lucrative returns. 


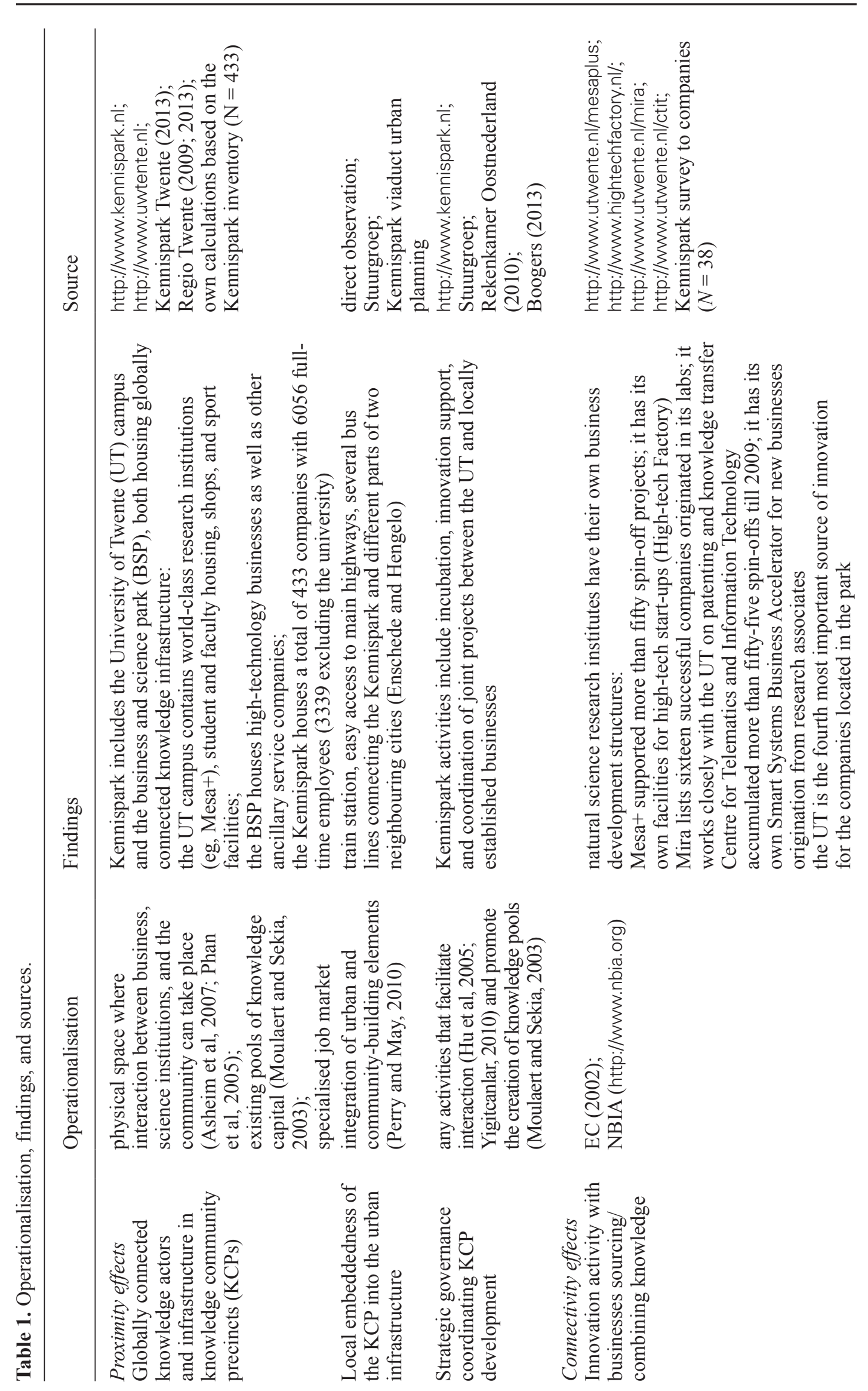




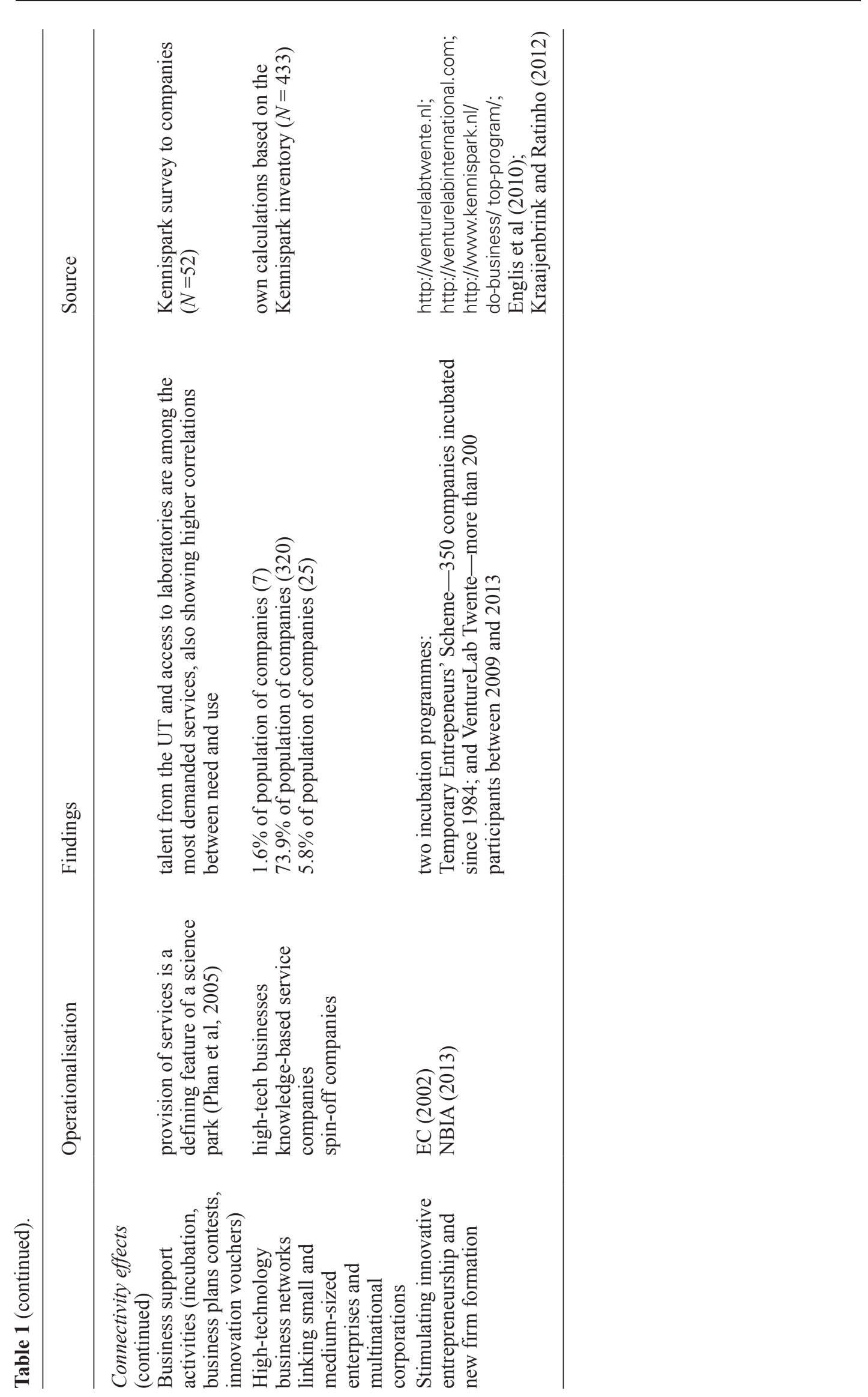


Table 2. Distribution of employment in the Kennispark firms.

\begin{tabular}{lccc}
\hline Category & Number of firms & $\%$ & Cumulative \% \\
\hline 0 & 141 & 32.6 & 32.6 \\
1 & 113 & 26.1 & 58.7 \\
$2-3$ & 60 & 13.9 & 72.5 \\
$4-5$ & 12 & 2.8 & 75.3 \\
$6-10$ & 41 & 9.5 & 84.8 \\
$11-20$ & 26 & 6.0 & 90.8 \\
$21-50$ & 23 & 5.3 & 96.1 \\
$51-250$ & 15 & 3.5 & 99.5 \\
$>250$ & 2 & 0.5 & 100.0 \\
\hline
\end{tabular}

ten employees (see table 2). The 433 organisations account for a total of 6056 full-time employees working at the Kennispark postcode locations. That includes 2657 employed at UT, with significant employers including an accountant's office and financial consultancy company (340), the CoC (190), a law company (143), and a civil law notary (120), then the first of two technology-based companies: Universal electronics (103) and XSens (94). The full employment distribution is shown in figure 4.

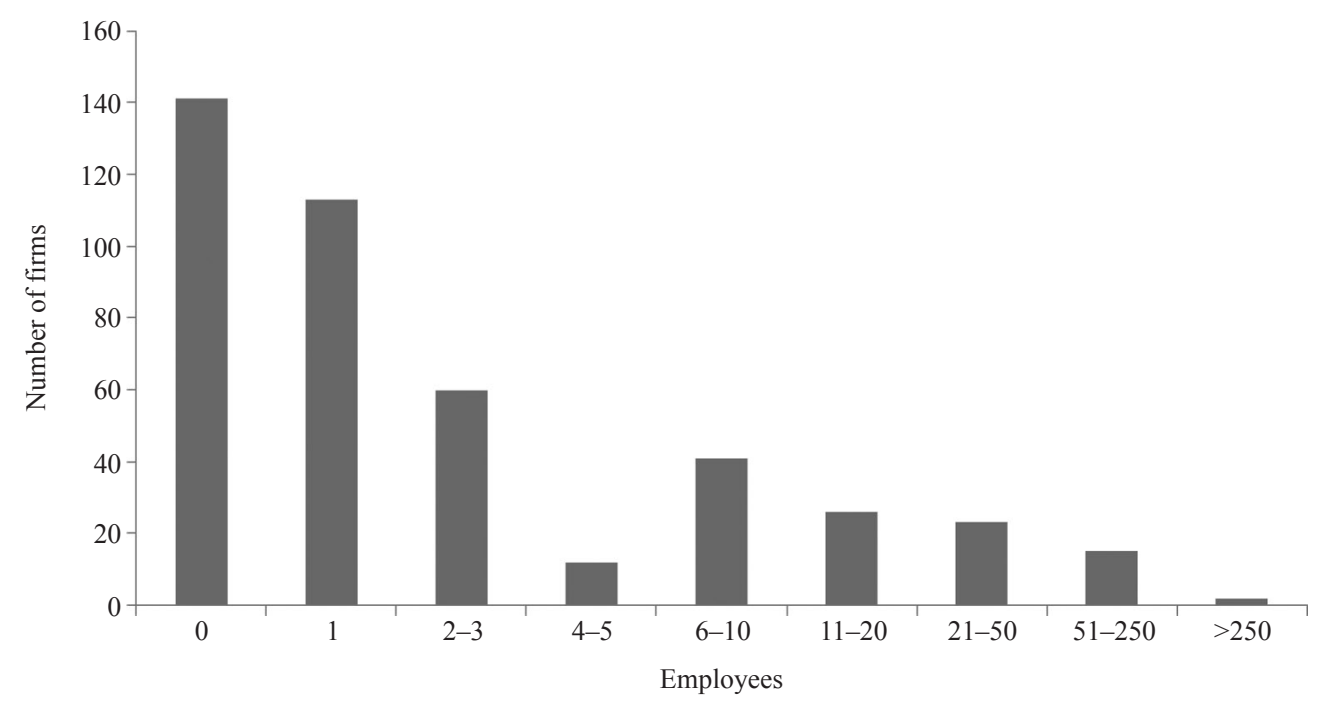

Figure 4. Employment at Kennispark by number of employees in companies (source: authors' own analysis of Chambers of Commerce data).

The nature of the globally connected knowledge base is interesting; the evidence suggests that it is dynamic as a consequence of being volatile and dependent on large numbers of very small firms engaged in innovation. These large numbers of innovative SMEs might suggest either many opportunities to exploit these knowledge pool assets (as with spin-off companies). Conversely, they might suggest a problem in joining up those assets, and people believe there may be a market in trying to fill them, using foundations as a way of limiting the potential losses if those barriers cannot be overcome.

Local embeddedness of the KCP into the urban infrastructure

A second Kennispark element was better integrating UT into Enschede's urban structure and the Twente conurbation. UT was originally a standalone edge-of-city campus, accentuated by its physical layout as a country park and proximity to protected forest land (Gellekink, 2001). 
Traffic was routed to the south of the campus along the elevated viaduct dual carriageway, both dividing the BSP from UT as well as disconnecting the university from the city. Connectivity emerged as an issue in 2004, with a strategy arguing to integrate UT and BSP and also better connect UT to the cities of Enschede and Hengelo. This involved a set of concrete activities whereby the viaduct was removed in a costly, slow, and politically contentious process [Benneworth et al (2011)] provide more detail on that episode]. Symbolically, the campus was integrated into the regular city planning process and incorporated into the built-up area. This supported private on-campus infrastructure investment, with the first phase being the speculative redevelopment of the Langezijds building as the investor-backed 'Gallery' building. At the time of writing, $11000 \mathrm{~m}^{2}$ of space has been developed on land formerly occupied by UT researchers, now rented to high-technology businesses. More recently, investment has been announced to create a high-quality public transport link from Hengelo station to Kennispark.

Part of the role played by infrastructure in the KPC can be regarded as being symbolic from the perspective of public sector investors, giving the municipalities a sense that they have a responsibility for the KPC, and justifying their infrastructure investments - such as the $€ 180$ million cost for the viaduct's removal. These investments made Kennispark a site for the realisation of public sector aims and goals, but at the same time also encouraged private investment. This private investment helped to attach Kennispark to wider capital flows in both physical infrastructure but also for technological investments. In the case of Kennispark, infrastructure has been more important in providing local anchors by which external investment is leveraged than shaping flows within the urban area.

\section{Strategic governance coordinating KCP development}

Kennispark is overseen by a partnership of province, city, and university, which strategically coordinates Kennispark's activities and services. Since the mid-1980s, UT and BSP have developed a large number of technology transfer, knowledge exchange, and cocreation activities [see Benneworth and Hospers (2007a) for more detail]. These services were primarily reactive to external subsidies or opportunities to exploit particular technologies. Although one programme - the Temporary Entrepreneurs' Scheme [the 'TOP' programme: cf Englis et al (2010), Kraaijenbrink and Ratinho (2012), and van der Sijde et al (2002)] — was successful in promoting a range of spin-outs, what these activities could not collectively do was invest in support infrastructure to embed these networks and projects into Kennispark's knowledge infrastructure.

In 2005 the province was sufficiently attracted by the idea of a physical Kennispark site, to allocate $€ 5$ million for site development. Three organisations came together to form the Kennispark organisation: the province's innovation team, part of the city's economic development group, and the university's technology transfer office, 'Twente Innovationlab'. Although the concrete ideas were present before the Kennispark Foundation formed (the Langezijds redevelopment was named in an interview with Twente Innovationlab in July 2006), the creation of a bureau allowed these plans' realisation. In 2007 a further set of investments were made in both R\&D and physical infrastructure (Regio Twente, 2009), and by 2013 Kennispark claimed to have invested $€ 156$ million (including university R\&D) in a total of $€ 275$ million R\&D investments creating over 3700 jobs in the Twente region (2007-12).

The role of strategic governance in the Kennispark project has been different from that suggested in the literature of mobilising and coordinating. The idea of the Kennispark emerged in 1999, the integrated campus in 2001, integrating into Enschede and Hengelo in 2007, all based on triangulating between what existing actors were doing, policy makers goals' to stimulate innovation in an eye-catching way, and trying to slightly improve those activities. The strategic governance contribution has been to develop the concept of Kennispark as a physical space and apply it to the reality of what existing researchers are doing in ways that have expanded Kennispark's knowledge footprint, in the hope of driving urban upgrading. 


\section{Connectivity elements}

Innovation activity with businesses sourcing and combining knowledge

One connectivity element is that firms engaged in modes of innovation involve combining different kinds of knowledge. We firstly explored the firms' active technology sector, using several official categorisations such as high technology, knowledge-based services aggregations (Eurostat, 2009) and spin-off firms, their legal status, and their presence within Deloitte's Fastest Fifty, a voluntary ranking of the Benelux's fifty top technology businesses. The majority of employment is not in high-technology manufacturing but rather business services: financial services are the most dominant (17.8\%, seventy-seven companies), followed by computer programming, consultancy, and related activities (12.0\%, fifty-two companies), with scientific R\&D ranked third (6.9\%, thirty companies). We analysed the technology intensity of industries using the Eurostat (2009) three-digit classification (table 3). We also see that the twenty-three manufacturing companies account for only 158 jobs, representing below $5 \%$ of total employment (excluding UT). Similarly, we see that knowledge-based services companies employ 3223 people, which translates into $94 \%$ of total employment (again excluding UT).

Table 3. Technology intensity of Kennispark firms, number of firms, and total employment (source: authors' own analysis of Chambers of Commerce data).

\begin{tabular}{lccc}
\hline Category & Number & $\%$ & Total employees \\
\hline Technology intensity & & & \\
High technology & 7 & 1.6 & 57 \\
Medium-high technology & 3 & 0.6 & 5 \\
Low-medium technology & 7 & 1.6 & 60 \\
Low technology & 6 & 1.2 & 36 \\
Others & 428 & 95.0 & 5898 \\
Knowledge-based services & & & \\
Knowledge-based services & 320 & 73.9 & 5283 \\
Less knowledge-based services & 85 & 19.7 & 597 \\
Others & 26 & 5.3 & 176
\end{tabular}

Computer programming and consultancy as well as scientific R\&D businesses were involved in bringing together knowledge from different sources, including from the universities and businesses (the financial services companies are primarily delivering standardised business services) (Benneworth and Hospers, 2007b). The survey subsequently shows how Kennispark companies were using both the university and their supply chain as important sources of knowledge, bringing together those different networks (university and corporate knowledge), creating businesses that in many cases grew and succeeded. There were also connections between different sectors - for example, in the way that both nanotechnology and material sciences and silicon microfabrication became incorporated into medical technology segments in products such as microsieves for medicine dosing or laboratory-on-a-chip products for home-based clinical diagnostic services. This emphasises that businesses - and not just the university — are knowledge combination sites.

\section{Business support activities}

The second connectivity element was high-technology services provision to innovative businesses. Data were drawn from the firm web survey, asking firms both their reported need for services and the frequency with which Kennispark satisfied those needs (figure 5). Recruitment of talent from the UT was the most demanded service among companies located 


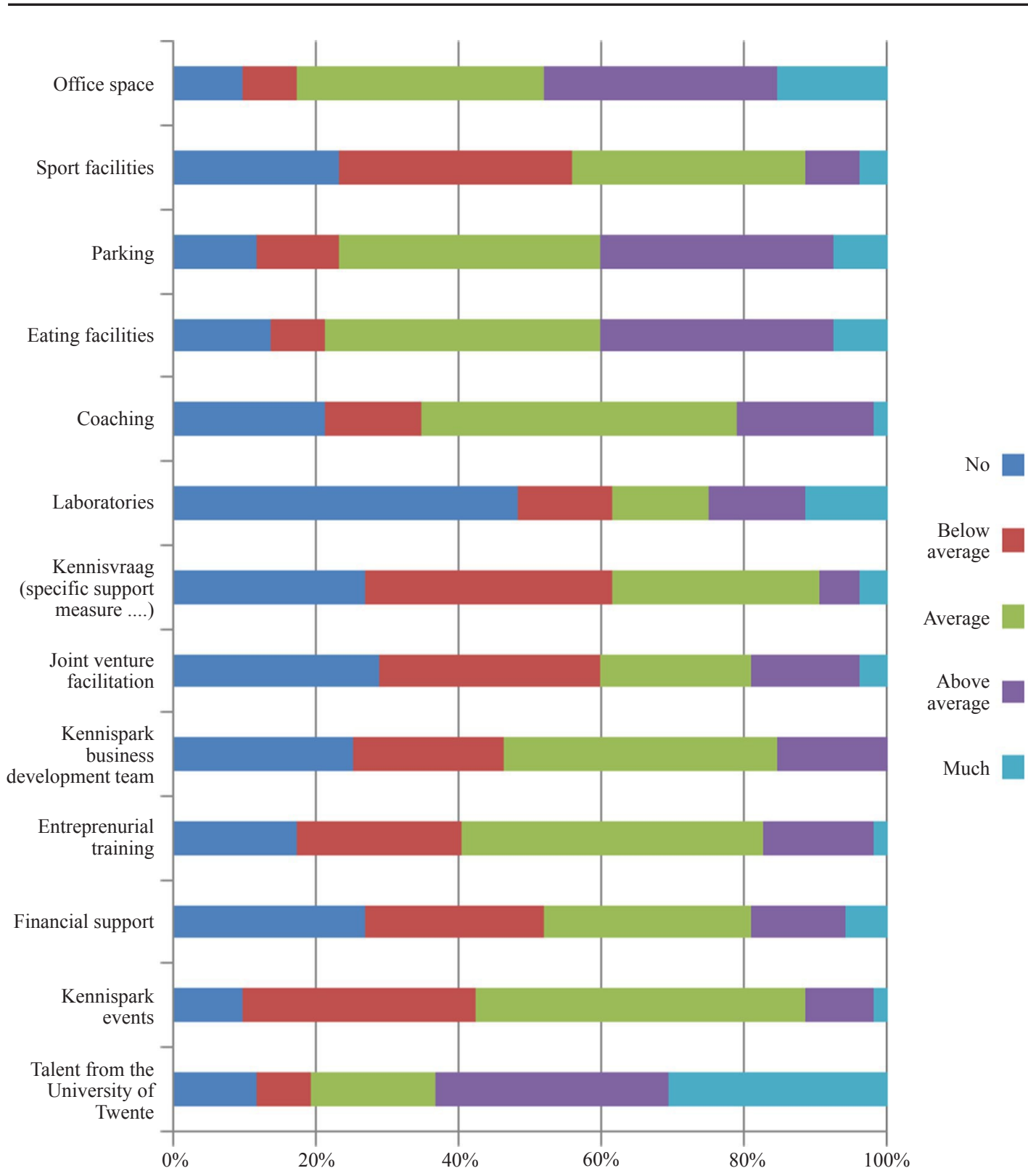

Figure 5. [In colour online.] Reported need for services provided by Kennispark $(N=52)$.

within the Kennispark, followed by office space, parking, and eating facilities. Notably, needs for financial support, coaching, training, and services for start-up companies rank much lower (figure 6).

Table 4 shows the areas of greatest demand for and the use of those services provided on the Kennispark. It appears significant that there is a relatively low reported use of traditional incubator services, such as coaching, entrepreneurship training, and assistance with accessing finance amongst existing entrepreneurial firms on Kennispark. Firms access university knowledge in terms of both student knowledge as well as laboratory facilities. Kennispark includes a number of projects and bureaus whose aim is to facilitate entrepreneurs' access to that knowledge, and thereby to specifically ease the knowledge resource constraint that many new entrepreneurs face - that knowledge resource facilitation function seems to be more useful to the firm than the formal incubator services. 


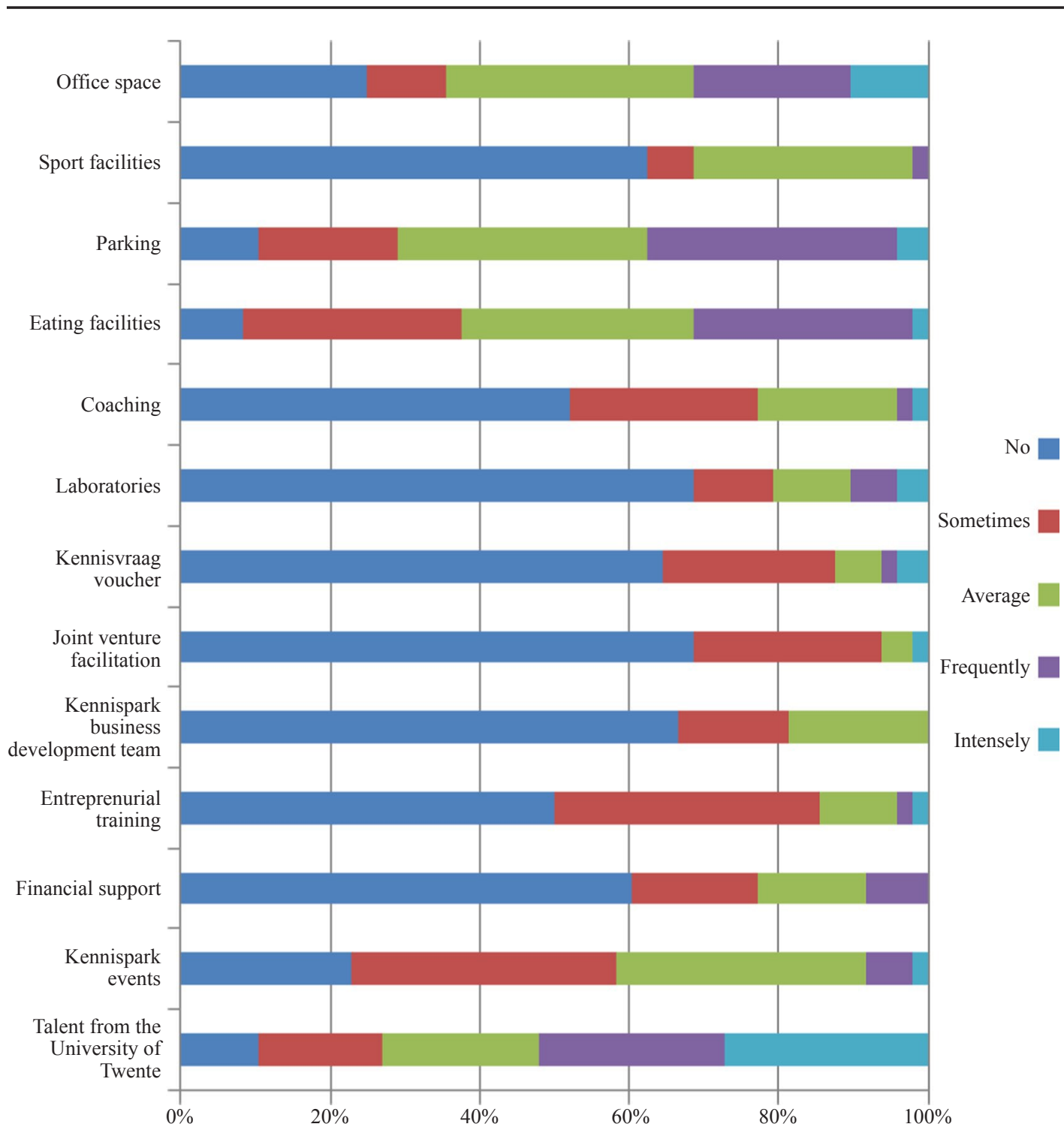

Figure 6. [In colour online.] Reported use of services provided by Kennispark $(N=52)$.

Table 4. The top-five services demanded and used by Kennispark innovators.

\begin{tabular}{lllr}
\hline Top five by demand & $\%$ & Top five by use & $\%$ \\
\hline Talent from the University of Twente (UT) & 63 & talent from UT & 52 \\
Office space & 48 & parking & 28 \\
Parking facilities & 40 & office space & 32 \\
Eating facilities & 40 & eating facilities & 31 \\
Access to laboratories & 26 & access to laboratories & 11 \\
\hline
\end{tabular}


High-technology business networks linking SMEs and MNCs

The third connectivity element was interaction between knowledge producers and users within the KCP. Despite the absence of high-technology manufacturing firms, $72 \%$ of the surveyed companies reported innovations within the last year (thirty-eight of fifty-two firms). Firms were asked to highlight significant sources of knowledge in innovation: after the usual sources of knowledge for innovation (internal and within the supply chain), the university was the fourth highest source of high-intensity and medium-intensity knowledge use (table 5), providing evidence that Kennispark helps those firms access knowledge (figure 7).

Table 5. Sources of innovation $(N=38)$.

\begin{tabular}{lrrrrrr}
\hline Sources of innovation & Not used & Low & Medium & High & Mean & SD \\
\hline Internal & 0 & 0 & 7 & 31 & 3.82 & 0.393 \\
Suppliers & 6 & 5 & 16 & 11 & 2.84 & 1.027 \\
Clients & 1 & 4 & 15 & 18 & 3.32 & 0.775 \\
Competitors & 5 & 13 & 18 & 2 & 2.45 & 0.795 \\
Consultants & 14 & 11 & 9 & 4 & 2.08 & 1.024 \\
University of Twente & 9 & 8 & 11 & 10 & 2.58 & 1.130 \\
Conferences and trade fairs & 10 & 10 & 14 & 4 & 2.32 & 0.989 \\
Scientific publications & 11 & 8 & 11 & 8 & 2.42 & 1.130 \\
Professional associations & 17 & 11 & 8 & 2 & 1.87 & 0.935 \\
\hline
\end{tabular}

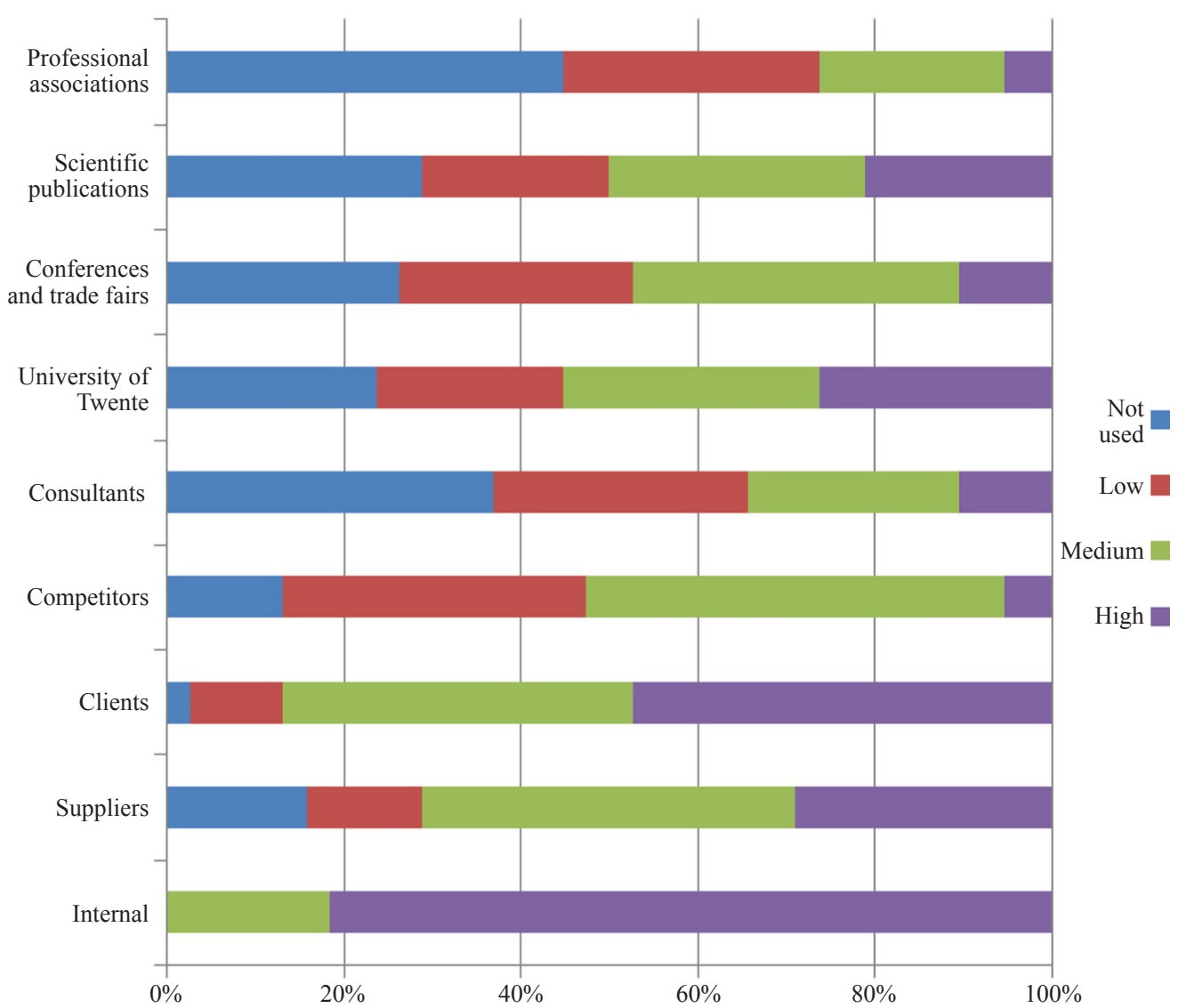

Figure 7. [In colour online.] Significant sources of knowledge reported by innovating firms $(N=38)$. 
This suggests an interesting topology in the knowledge networks around Kennispark; whilst the wider knowledge collectivities for the firms are corporate innovation networks often headed by high-technology customers, the local knowledge community is strongly anchored around the university, with $60 \%$ of responding firms reporting medium or high-intensity use of university knowledge. This could be interpreted as an interesting twist in the idea of universities as global pipelines providing local buzz (Bathelt et al, 2004). The global pipelines are at least partly provided by firms on Kennispark, and the university at Kennispark provides the space within which that local buzz is generated, it then being embedded by those firms.

\section{Stimulating innovative entrepreneurship and firm formation}

We investigated Kennispark's involvement in incubation programmes and business support activities focused on business creation. Kennispark has been active in technology entrepreneurship programmes since 1984, the year the TOP programme was created. That scheme provides a loan for potential entrepreneurs to work with a university research group and a business mentor for a year to develop a business plan and secure external continuation funding (Clarysse et al, 2005; van der Sijde et al, 2002). The most conservative estimate of the number of companies this has formed to date is 350 (Englis et al, 2010; Kraaijenbrink and Ratinho, 2012), each project involving the active and supported combination of university and external resources into a new business: our databases show that at least two thirds of these are still active (Englis et al, 2010). A second scheme was the VLT programme, initiated in 2009: this scheme supported entrepreneurs with a high-growth potential idea, providing them with a physical location, training programme, and connections into regional knowledge networks to support that growth. That programme has had over 200 participants since its inception, and provides a means of connecting knowledge producers and users - and their wider local networks - to create activities physically located and connected in Twente. ${ }^{(4)}$

Although several of the entrepreneurship promotion projects and schemes predate Kennispark's creation, a critical element has been progressing beyond individual projects to creating additive connective services and infrastructures where universal knowledge is fixed into specific technologies, and one actor (the university) becomes two (university plus entrepreneur); their additionality comes through the external resources they attract for commercialising those technologies, as well as representing new nodes in commercialisation networks. In the context of entrepreneurs with bounded competencies and resources, the university and its existing connections can be drawn upon by those entrepreneurs seeking to create high-technology businesses; indeed, the activities have started to codify and script these network connections into particular behavioural routines within the entrepreneurship projects (cf Rasmussen et al, 2011).

\section{KCPs' innovation dynamics}

\section{Kennispark's proximity effects}

Clearly, one element of the Kennispark site is to attract a range of actors with their own external networks into a location, and create the opportunities for spillover effects to emerge: the proximity or precinct effects. The first group are high-technology actors and their employees who have knowledge resources appropriate for creating new businesses that add to Twente's overall economic strength. Some are already located in Twente but develop through the change of role (such as when postdoctorates from the university become entrepreneurs); others are attracted to the Twente region because of the complementary nature of the technological knowledge there in the KPC between university and local businesses (including MNCs).

${ }^{(4)}$ See VLT website at http://venturelabtwente.nl/bedrijfsontwikkeling-voor-beginnende-bedrijven-groeiversneller/ 
A second group are those that are attracted by this first group, and who make a series of investment and governance decisions that realise the physical space. This includes those with the external financial connections to invest in these 'knowledge transformations' taking value propositions and creating new activities which generate economic value. Related are external financiers who invest in the real estate in order to profit from the technological interactions and commercialisation activities taking place. Finally are public policy actors (all in their own wider multilevel governance systems), who come together to create a physical space, supported by property investors, who in turn rely on the second group to fund the first group to create new technology businesses.

Much of the literature and debate has focused on bringing these globally well-connected actors into physically proximate spaces; some have been enthusiastic of the possibilities this creates, whilst others have been more critical of a tendency to create latter-day cathedrals in the desert (cf Brooker, 2013). Our findings reiterate a contingently constructive interrelation between these two positions. The work on developing precinct effects creates the basis for the community effects, but community effects do not necessarily spontaneously emerge. It is not enough merely to bring globally connected actors together-rather, this active work developing the connectivity of actors (and creating new actors embedded in these communities) in these precincts also has value.

\section{Kennispark's connectivity effects}

A second important element of Kennispark were connectivity effects, and constructing a community interacting and innovating within the precinct. We highlight the sense that these actors have a built-in connectivity to other actors in the system, creating shared interests and rationales behind interactions. The most obvious example of this are those high-technology firms created with a natural connectivity to the university, as well as the existence of institutions to facilitate that connectivity. One of the greatest problems that spin-offs face in general is establishing their organisational independence (Clausen and Rasmussen, 2013; Rasmussen et al, 2011; Vohora et al, 2004): the UT spin-off mechanisms appear to avoid this by emphasising the entrepreneur's independence from the start, and permit the entrepreneur to work with the university only where there is clear mutual benefit in so doing. ${ }^{(5)}$

The net effect is a community formed by entrepreneurs, support services, investors, and academics involved in shared knowledge exchange-these connections underpin employment movement, with students progressing into spin-off firms whilst retaining their informal links back to the university research groups. Although not emerging in this survey, the Deloitte's Fastest Fifty for Benelux highlights the high-technology growth potential in Kennispark companies. Although accounting for less than 3\% of the Benelux labour market, Kennispark firms have consistently been visible in this ranking, with four entries in 2013, two entries in 2011, four in 2008 and 2010, and five entries in 2009 (including the winner, Service 2 Media). At least some spin-off companies grow into globally oriented high-technology firms with their own connections. They bring resources back into the precinct and contribute to its overall development both physically and in terms of the creative communities, strengthening the knowledge community within a wider set of corporate knowledge collectivities.

At the same time, this community-building and extending activity depends on Kennispark's 'precinct' elements. New firms do rely on the university and other firms; they also benefit from being embedded in the local labour market as well as from the specific targeted policy interventions from Kennispark and other policy actors. Although when TOP started, the university was the main globally networked actor, an important part of the community

${ }^{(5)}$ This contrasts to situations where firms emerge sotto voce within research groups and become a way for academics to bypass university financial regulations (cf Zomer et al, 2010). 
around Kennispark are mature spin-off companies with multiple community roles. For the universities they are knowledge users and partners; they are knowledge suppliers to external MNCs; they are mentors, allies, and even investors for the next generation of spin-offs; for the property businesses they offer a rental stream; and for policy makers they demonstrate the validity of the policy. Thus, we hypothesise that one of the strengths of Kennispark as a $\mathrm{KCP}$ is that it has been able to incorporate an existing knowledge community, and to use the precinct to strengthen and formalise its operation. The proximity elements are just as necessary as the connectivity elements.

\section{Incorporating connectivity effects in KBUD theory}

It is the apparent interdependence of the elements - between the precinct and the community aspects - that we find most interesting. As previously identified, contemporary 'confused' KBUD conceptualisations focus on precinct elements-individual actors attracted to that built environment, its physical connectivity, and those services created to encourage innovation. Kennispark demonstrates that KCP coherence can be understood in terms of an additional set of processes of a knowledge community embedded in a wider set of knowledge collectivities (following Lindkvist, 2005; Loasby, 1998). We here acknowledge that Twente is a specific regional case study where substantive upgrading of the cross-city connectivity of regional actors remains to be demonstrated, therefore limiting our claims' generalisability. Likewise, Kennispark's directed elements do not account for all the region's innovation: one of the region's most visible high-growth high-technology firms, Takeaway.com, was created by a UT student who never completed their university degree. ${ }^{(6)}$

Nevertheless, in understanding how KCPs emerge and function, we should consider in parallel the interactive building of precincts and knowledge communities. Although much is known about the functioning and dynamics of local university-industry knowledge communities (cf Blažek and Žížalová, 2010; Etzkowitz, 2012; Gertner et al, 2011; Kasabov, 2008), much less is known about how to actively build these communities in particular places to stimulate KBUD. This is particularly apposite given that these local knowledge communities are themselves embedded in wider networks that can be conceptualised at a variety of scales, including networks of practice, epistemic communities and knowledge collectivities, or even imagined communities (cf Amin and Roberts, 2008).

The Kennispark case hints that the KCP provided a means for an existing knowledge community to grow, reinforce itself, and develop new capacities. The SP literature appears to offer a useful set of conceptual tools in this regard for understanding how existing communities fit into new precincts (Hansson et al, 2005). This fits with the well-established point that those SPs which work best are those already embedded around strong and supportive knowledge communities able to exploit the new facilities (Massey et al, 1992; Quintas et al, 1992). Nevertheless, we argue that more consideration needs to be given to these proximity-connectivity processes in KBUD conceptualisation, as well as an imperative to understanding how this dynamic within-city process in turn drives cross-city connectivity and ultimately upgrading effects, the latter stages of our figure 1 model.

Ours is an exploratory empirical piece of research seeking to reflect on the confused KBUD concept via a single case study; clearly, it would be useful to introduce a comparative dimension to this analysis to place the findings in a broader context. It would also be useful to explore cross-city connectivity effects, potentially making Twente more of a 'place to be' within the various technical medicine, nanotechnology, and ICT applications SISs, and ultimately driving urban upgrading. This in turn would be helpful in developing

${ }^{(6)}$ http://www.intermediair.nl/carriere/een-baan-vinden/bereopen-functies/oprichter-thuisbezorgdnl-desite-was-het-begin-niet-zo-handig 
a comprehensive multiscalar conceptualisation of territorial innovation that would make KBUD in theory and practice most useful to its respective stakeholders.

With that caveat, we nevertheless believe that our findings have wider implications for KBUD in theory and practice, and, in particular, literature relating to the management and governance of KBUD. More consideration needs to be given to constructing knowledge community connectivity in strategic urban science projects. This raises interesting future research questions about how local communities engage and enrol external actors and embed their resources into these precinct communities. From a practical perspective, there is a need to develop instruments and policies to embed knowledge communities within emergent knowledge districts, and to identify the key areas of leverage and dynamism. Kennispark's strength came from a genealogy of university-related spin-off and start-up companies, but one might hypothesise that a large lead firm with an open innovation campus could have comparable effects with a different but tailored policy mix (cfTödtling et al, 2011). This should allow those KBUD projects which do emerge to realise their full economic development potential, and help contribute to building more competitive and innovative knowledge cities.

Acknowledgements. We gratefully thank Oscar Lustig and Ton Masselink for this paper's data collection, which was part of their graduation projects, and to respondents to the questionnaire and interviewees for their time and input. Also, we would like to express our gratitude to Dr Kees Eijkel, managing director of Kennispark, whose institutional endorsement of our web survey contributed to our acceptable response rate. Jantsje op de Hoek, account manager at Kennispark, was also of great value with her daily assistance to Oscar with his research, which helped us in shaping the survey. Many thanks are also due to the editors and Professor Phelps's remarks as well as two anonymous referees for their comments on two earlier versions of the manuscript, which were very helpful in improving the paper. Any errors or omissions remain our responsibility.

\section{References}

Amin A, 1999, "An institutional perspective on regional development" International Journal of Urban and Regional Development 23 365-378

Amin A, Roberts J, 2008, "Knowing in action: beyond communities of practice" Research Policy 37 353-369

Amirahmadi H, Saff G, 1993, "Science parks: a critical assessment" Journal of Planning Literature 82 107-123

Asheim B, Coenen L, Vang J, 2007, "Face-to-face, buzz, and knowledge bases: sociospatial implications for learning, innovation, and innovation policy" Environment and Planning C: Government and Policy 25 655-670

Asheim B T, Boschma R, Cooke P, 2011, "Constructing regional advantage: platform policies based on related variety and differentiated knowledge bases" Regional Studies 45 893-904

Bathelt H, Malmberg A, Maskell P, 2004, "Clusters and knowledge: local buzz, global pipelines and the process of knowledge creation" Progress in Human Geography 28 31-56

Benner C, 2003, "Learning communities in a learning region: the soft infrastructure of cross-firm learning networks in Silicon Valley" Environment and Planning A 35 1809-1830

Benneworth P, Dassen A, 2011, "Strengthening global-local connectivity in regional innovation strategies" WP 01/2011, OECD Regional Development, Paris, http://www.oecd-libraryorg/governance/oecd-regional-development-working-papers_20737009

Benneworth P S, Hospers G J, 2007a, "Urban competitiveness in the knowledge economy: universities as new planning animateurs" Progress in Planning 23 3-102

Benneworth P, Hospers G J, 2007b, “The new economic geography of old industrial regions: universities as global-local pipelines" Environment and Planning C: Government and Policy $25779-802$

Benneworth P, Ratinho T, 2014, "Regional innovation culture in the social knowledge economy", in The Social Dynamics of Innovation Networks Eds R Rutten, P Benneworth, D Irawati, F Boekema (Routledge, London) pp 239-256 
Benneworth P, Hospers G J, Jongbloed B, Leiyste L, Zomer A, 2011, "The 'science city' as a system coupler in fragmented strategic urban environments?" Built Environment 37 317-335

Benneworth P, Irawati D, Rutten R, Boekema F, 2014, "The social dynamics of innovation networks: from learning region to learning in socio-spatial context", in The Social Dynamics of Innovation Networks Eds R Rutten, P Benneworth, D Irawati, F Boekema (Routledge, London) (forthcoming)

Bigliardi B, Dormio A I, Nosella A, Petroni G, 2006, “Assessing science parks’ performances: directions from selected Italian case studies" Technovation 26 489-505

Blažek J, Žížalová P, 2010, “The biotechnology industry in the Prague metropolitan region: a cluster within a fragmented innovation system?" Environment and Planning C: Government and Policy 28 887-904

Bøllingtoft A, 2012, "The bottom-up business incubator: leverage to networking and cooperation practices in a self-generated, entrepreneurial-enabled environment" Technovation 32 304-315

Boogers M, 2013, "Het raadsel van de Regio waarom regionale samenwerking soms resultaten oplevert", inaugural professorial lecture, 17 October, Universiteit Twente, Enschede, http:// wwwutwentenl/mb/pa/staff/boogers/publications/ 7020\%200ratieboekje\%20Boogers\%20LRpdf

Brooker D, 2013, "From 'wannabe' Silicon Valley to global back office? Examining the socio-spatial consequences of technopole planning practices in Malaysia" Asia Pacific Viewpoint 54 1-14

Bruneel J, Ratinho T, Clarysse B, Groen A, 2012, "The evolution of business incubators: comparing demand and supply of business incubation services across different incubator generations" Technovation 32 110-121

Castells M, Hall P, 1994 Technopoles of the World: The Making of Twenty-first-century Industrial Complexes (Routledge, London)

Clarysse B, Wright M, Lockett A, Van de Velde E, Vohora A, 2005, "Spinning out new ventures: a typology of incubation strategies from European research institutions" Journal of Business Venturing 20 183-216

Clausen T, Rasmussen E, 2013, "Parallel business models and the innovativeness of research-based spin-off ventures" The Journal of Technology Transfer 38 836-849

Coe N M, Hess M, Yeung H W-C, Dicken P, Henderson J, 2004, “Globalizing' regional development: a global production networks perspective" Transactions of the Institute of British Geographers, New Series 29 468-484

Cooke P, 2002, "Biotechnology clusters as regional, sectoral innovation systems" International Regional Science Review 25 8-37

Cooke P, 2005, "Regionally asymmetric knowledge capabilities and open innovation: exploring 'Globalisation 2'- a new model of industry organisation" Research Policy 34 1128-1149

Cooke P, Morgan K, 1998 The Associational Economy (Oxford University Press, Oxford)

Crevoisier O, 2014, "Beyond territorial innovation models: the pertinence of the territorial approach" Regional Studies 48(3), doi:10.1080/00343404.2011.602629

EC, 2002 Benchmarking of Business Incubators: Final Report (European Commission, Brussels)

Englis P D, Ratinho T, Englis B G, 2010, "Extensiveness of business planning and firm performance: an examination into the drivers of success and survival for startup firms", Rent XXIV 'The Entrepreneurial Process in a Changing Economy', Maastricht, http://purl.otwente.nl/publications/74407

Etzkowitz H, 2012, "Triple helix clusters: boundary permeability at university-industry-government interfaces as a regional innovation strategy" Environment and Planning C: Government and Policy 30 766-779

Eurostat, 2009, “' 'High-technology' and 'knowledge based services' aggregations based on NACE Rev 2", Luxembourg

Forsyth A, 2014, "Alternative forms of the high technology district: corridors, clumps, cores, campuses, subdivisions, and sites" Environment and Planning C: Government and Policy 32

Garlick S, Benneworth P, Puukka J, Vaessen P, 2006, “ 'Twente, the Netherlands' the regional contribution of higher education institutions", peer review report, Institutional Management in Higher Education programme, OECD, Paris 
Gellekink A, 2001, "Drienerlo, van landgoed tot campusuniversiteit", in Van landgoed tot kenniscampus 1961-2001 Ed. B Groenman (University of Twente Press, Enschede) pp 32-37

Gertler M S, 2003, "Tacit knowledge and the economic geography of context, or the undefinable tacitness of being there" Journal of Economic Geography 3 75-99

Gertner D, Roberts J, Charles D, 2011, "University-industry collaboration: a CoPs approach to KTPs" Journal of Knowledge Management 15 625-647

Glückler J, 2007, "Economic geography and the evolution of networks" Journal of Economic Geography 75 619-634

Hansson F, Husted K, Vestergaard J, 2005, "Second generation science parks: from structural holes jockeys to social capital catalysts of the knowledge society Technovation 25 1039-1049

Håkanson L, 2005, "Epistemic communities and cluster dynamics: on the role of knowledge in industrial districts" Industry and Innovation 12 433-463

Hu T-S Lin, C-Y, Chang S-L, 2005, "Technology-based regional development strategies and the emergence of technological communities: a case study of HSIP, Taiwan" Technovation 25 $367-380$

Huggins R, Johnston A, 2009, "The economic and innovation contribution of universities: a regional perspective" Environment and Planning C: Government and Policy 27 1088-1106

Kasabov E, 2008, "The challenge of devising public policy for high-tech, science-based, and knowledge-based communities: evidence from a life science and biotechnology community" Environment and Planning C: Government and Policy 26 210-228

Kennispark Twente, 2013, “Twentse Innovatieroute 2007-13: Samen werken aan innovatie", Enschede

Kim H, Lee Y S, Hwang H R, 2014, "Regionalization of planned science and technology parks: the case of the Daedeok S\&T Park in Daejeon, South Korea" Environment and Planning C: Government and Policy 32

Knopp L, 2007, "2006 state of the business incubation industry”, National Business Incubation Association, Athens, $\mathrm{OH}$

Kraaijenbrink J, Ratinho T, 2012, "Causal and creative modes of entrepreneurial strategizing: a content analysis of business plans of small and micro firms", Academy of Management Annual Meeting Conference, Boston, MA

Lagendijk A 2007, "The accident of the region: a strategic relational perspective on the construction of the region's significance" Regional Studies 41 1193-1207

Lagendijk A, 2011, "Regional innovation policy between theory and practice", in Handbook of Regional Innovation and Growth Eds P Cooke, B Asheim, R Boschma, R Martin, D Schwartz, F Tödtling (Edward Elgar, Cheltenham, Glos) pp 597-608

Lagendijk A, Oïnas P, 2005, "Proximity, external relationships and local economic development", in Proximity, Distance and Diversity: Issues on Economic Interaction and Local Development Eds A Lagendijk, P Oïnas (Ashgate, Aldershot, Hants) pp 3-22

Lawton Smith H, 2007, "Universities, innovation, and territorial development: a review of the evidence" Environment and Planning C: Government and Policy 25 98-114

Leibovitz J, 2003, "Institutional barriers to associative city-region governance: the politics of institution-building and economic governance in 'Canada's Technology Triangle" "Urban Studies 40 2613-2642

Lindkvist L, 2005, "Knowledge communities and knowledge collectivities: a typology of knowledge work in groups" Journal of Management Studies 42 1189-1210

Link A N, Scott J T, 2003, "US science parks: the diffusion of an innovation and its effects on the academic missions of universities" International Journal of Industrial Organization 21 1323-1356

Livi C, Hugues J, Crevoisier O, 2014, "From regional innovation to multi-local valuation milieus: the case of the Western Switzerland photovoltaic industry", in The Social Dynamics of Innovation Networks Eds R Rutten, P Benneworth, D Irawati, F Boekema (Routledge, London) pp 23-41

Loasby B J, 1998, “The organisation of capabilities" Journal of Economic Behavior and Organization 35 139-160 
Löfsten H, P Lindelöf, 2002, "Science parks and the growth of new technology-based firms: academic-industry links, innovation and markets" Research Policy 31 859-876

Longhi C, Quéré M, 1993, "Innovative networks and the technopolis phenomenon: the case of Sophia-Antipolis" Environment and Planning C: Government and Policy 11 317-330

Lovering J, 1999, “Theory led by policy: the inadequacies of the 'new regionalism' illustrated from the case of Wales" International Journal of Urban and Regional Research 23 379-395

McAdam M, McAdam R, 2008, "High tech start-ups in university science park incubators: the relationship between the start-up's lifecycle progression and use of the incubator's resources" Technovation 28 277-290

McCann P, Ortega-Argilés R, 2013, "Modern regional innovation policy" Cambridge Journal of Regions, Economy and Society 62 187-216

Massey D, Quintas P, Wield D, 1992 High-tech Fantasies: Science Parks in Society, Science and Space (Routledge, London)

Mattes J, 2006, "Innovation in multinational companies: an empirical analysis of innovation networks between globalisation and localisation", Bamberger Beiträge zur Europaforschung und zur internationalen Politik Nr. 14/2006, University of Bamberg, Bamberg

May T, Perry B, 2011, "Urban research in the knowledge economy: context, content and outlook" Built Environment 37 352-367

Miller S, 2014, "The Strathclyde technology and innovation centre in Scotland's innovation system" Regional Studies (forthcoming)

Moulaert F, Sekia F, 2003, "Territorial innovation models: a critical survey" Regional Studies 37 289-302

Nijkamp P, 2003, "Entrepreneurship in a modern network economy" Regional Studies 37 395-405

Norrman C, Bager-Sjögren L, 2010, "Entrepreneurship policy to support new innovative ventures: is it effective?" International Small Business Journal 28 602-619

OECD, 2007 Higher Education and Regions: Globally Competitive, Regionally Engaged (OECD, Paris)

Patton D, Warren L, Bream D, 2009, "Elements that underpin high-tech business incubation processes" The Journal of Technology Transfer 34 621-636

Perry B, 2008, "Academic knowledge and urban development: theory, policy and practice", in Knowledge-based Urban Development: Planning and Applications in the Information Era Eds T Yigitcanlar, K Velibeyoglu, S Baum (Information Science Reference, New York) pp 21-41

Perry B, May T, 2010, "Urban knowledge exchange: devilish dichotomies and active intermediation" International Journal of Knowledge-Based Development 1 6-24

Phan P H, Siegel D S, Wright M, 2005, "Science parks and incubators: observations, synthesis and future research" Journal of Business Venturing 20 165-182

Phelps N A, Tewdwr-Jones M, 1998, "Institutional capacity building in a strategic policy vacuum: the case of the Korean company LG in South Wales" Environment and Planning C: Government and Policy 16 735-755

Popp Berman E, 2011 Creating the Market University: How Academic Science became an Economic Engine (Princeton University Press, Princeton, NJ)

Quintas P, Wield D, Massey D, 1992, “Academic-industry links and innovation: questioning the science park model" Technovation 12 161-175

Rasmussen E, Mosey S, Wright M, 2011, "The evolution of entrepreneurial competencies: a longitudinal study of university spin-off venture emergence" Journal of Management Studies 48 1314-1345

Ratinho T, Henriques E, 2010, "The role of science parks and business incubators in converging countries: evidence from Portugal" Technovation 30 278-290

Regio Twente, 2009 De agenda van Twente Enschede

Regio Twente, 2013 Ontwikkelingsagenda Netwerkstad Twente Deel2 Werkprogramma: samen investeren voor Twente Enschede

Rekenkamer Oostnederland, 2010 Op koers? Een onderzoek naar de Innovatieroute Twente Almelo 
Roberts J, 2014, "Community and the dynamics of spatially distributed knowledge production: the case of Wikipedia", in The Social Dynamics of Innovation Networks Eds R Rutten, P Benneworth, D Irawati, F Boekema (Routledge, London) pp 180-200

Sarimin M, Yigitcanlar T, 2012, "Towards a comprehensive and integrated knowledge-based urban development model: status quo and directions" International Journal of Knowledge-Based Development 3 175-192

Shane S, 2009, "Why encouraging more people to become entrepreneurs is bad public policy" Small Business Economics 33 141-149

Smith R G, 2003, "World city actor networks" Progress in Human Geography 27 25-44

Smith R G, 2014, "Beyond the global city concept and the myth of "command and control"" International Journal of Urban and Regional Research 38 98-115

Storper M, 1995, "The resurgence of regional economies ten years later: the region as a nexus of untraded interdependencies" European Urban and Regional Studies 2 191-221

Stuurgroep Kennispark, 2008 Masterplan gebiedsontwikkeling Kennispark Twente [Masterplan for spatial development of the Kennispark Twente site] Kennispark Foundation, Enschede

Tödtling, F, Prud'homme van Reine P, Dörhöfer S, 2011, “Open innovation and regional culture: findings from different industrial and regional settings" European Planning Studies 19 1885-1907

van Boom N, Mommaas H, 2009, "Case study 1: Tilburg/Enschede: urban regimes and evolutionary paths", in Transformation Strategies for Former Industrial Cities Eds N van Boom, H Mommaas (NAi, Amsterdam) pp 74-97

van der Sijde P, Karnebeck S, van Benthem J, 2002, "The impact of a university spin off programme: the case of HTSFs established through TOP", in New Technology Based Firms in the Millennium: Volume 2 Eds R Oakey, W During, S Kauser (Pergamon, London) pp 19-30

van Winden W, van den Berg L, Pol P, 2007, "European cities in the knowledge economy: towards a typology" Urban Studies 44 525-549

Vohora A, Wright M, Lockett A, 2004, "Critical junctures in the development of university high-tech spinout companies" Research Policy 33 147-175

Wolfe D A, 2010, "The strategic management of core cities: path dependence and economic adjustment in resilient region" Cambridge Journal of Regions, Economy and Society 31 139-152

Yigitcanlar T, 2010, "Making space and place for the knowledge economy: knowledge-based development of Australian cities" European Planning Studies 18 1769-1786

Yigitcanlar T, Velibeyoglu K, 2008, "Knowledge-based urban development: the local economic development path of Brisbane, Australia" Local Economy 23 195-207

Yin R, 2008 Case Study Research: Design and Methods (Sage, Thousand Oaks, CA)

Zomer A H, Jongbloed B W A, Enders J, 2010, "Do spin-offs make the academics' heads spin? The impacts of spin-off companies on their parent research organisation" Minerva 48 331-353 